ISSN: 2338-4328 (Print), ISSN: 2686-2646 (Online)

\title{
SISTEM LAYANAN DOOR TO DOOR PRODUK TABUNGAN SAAT PANDEMI COVID-19 PADA LEMBAGA PERKREDITAN DESA (LPD) DESA PAKRAMAN UBUD
}

\author{
Ni Wayan Rina Yanti ${ }^{1{ }^{*}}$, I Ketut Suamba ${ }^{2)}$, Gede Mekse Korri Arisena ${ }^{3)}$ \\ 1) Program Studi Agribisnis, Fakultas Pertanian, Universitas Udayana, Bali, Indonesia. \\ ${ }^{2 * 3)}$ Program Studi Agribisnis, Fakultas Pertanian, Universitas Udayana, Bali, Indonesia. \\ *E-mail: ${ }^{1}$ wayanrina10yahoo.co.id, ${ }^{2}$ ketutsuamba@unud.ac.id, ${ }^{3}$ korriarisena@unud.ac.id
}

\begin{abstract}
Abstrak
Salah satu strategi pemasaran yang dilakukan untuk memberikan kepuasan dan meningkatkan nasabah adalah melalui sistem layanan door to door atau melalui pemasaran langsung dengan sistematikanya adalah mendatangi ke rumah masing-masing. Salah satu lembaga keuangan yang menggunakan pendekatan pemasaran dengan sistem layanan door to door kepada nasabah yaitu LPD Desa Pakraman Ubud. Tujuan penelitian ini adalah untuk mengetahui karakteristik nasabah sistem layanan door to door, mengetahui proses pelaksanaan sistem layanan door to door pada LPD Desa Pakraman Ubud saat pandemi Covid-19, dan untuk mengetahui kelebihan dan kekurangan dari sistem layanan door to door pada LPD Desa Pakraman Ubud. Sampel dari penelitian ini sebanyak 50 responden yaitu 7 orang karyawan LPD dengan teknik purposive sampling dan 43 orang nasabah dengan teknik accidental sampling. Jenis penelitian yang digunakan adalah deskriptif kualitatif dengan teknik pengumpulan data adalah wawancara dan dokumentasi. Hasil penelitian menunjukkan sebagian besar nasabah masih berusia produktif dengan pekerjaan pedagang. Saat pandemi Covid -19, adanya perbedaan proses pelaksanaan sistem layanan door to door dari sebelumnya pada LPD Desa Pakraman Ubud seperti jam kerja yang berkurang, jumlah nasabah yang aktif menabung berkurang, dan jumlah setoran tabungan juga berkurang setiap bulannya pada tahun 2020. Penelitian ini mengharapkan pihak LPD Desa Pakraman Ubud konsisten dalam menerapkan prosedur yang telah ditetapkan untuk meminimalisir kesalahan-kesalahan yang tidak diinginkan dalam proses pelaksanaan sistem layanan door to door.
\end{abstract}

Kata kunci: Sistem Layanan Door to door; Covid-19; Lembaga Perkreditan Desa

\section{DOOR TO DOOR SERVICE SYSTEM FOR SAVING PRODUCT DURING THE COVID-19 EPIDEMIC AT THE LEMBAGA PERKREDITAN DESA (LPD) DESA PAKRAMAN UBUD}

\begin{abstract}
One of the marketing strategies undertaken to provide satisfaction and increase customers is through the door to door service system or through direct marketing with the system of visiting each other's homes. One of the financial institutions that use a marketing approach with a door to door service system to customers is LPD Desa Pakraman Ubud. The purpose of this study was to determine the characteristics of the door to door service customer, to know the process of implementing the door to door service system at the Pakraman Village LPD during the Covid-19 pandemic, and to determine the advantages and disadvantages of the door to door service system at the LPD Desa Pakraman Ubud. The sample of this study was 50 respondents, namely employees of LPD with purposive sampling technique and 43 customers with accidental sampling technique. The type of research used is descriptive qualitative with data collection techniques are interviews and documentation. The results showed that most of the customers were still in their productive age with the work of traders. During the Covid-19 pandemic, there were differences in the process of implementing the door to door service system from the previous LPD Desa Pakraman Ubud such as reduced working hours, reduced number of active customers saving, and the number of savings deposits also decreased every month in 2020. This study expects the LPD Desa Pakraman Ubud to be consistent in implementing established procedures to minimize unwanted errors in the process of implementing the door to door service system.
\end{abstract}

Keywords: Door to door service system, Covid-19; Lembaga Perkreditan Desa

Article History: Received:01 Maret 2021 Revised: 27 Maret 2021

Accepted: 08 April 2021 


\section{SULTANIST: Jurnal Manajemen dan Keuangan, Vol 9 (1), Juni 2021}

\section{PENDAHULUAN}

Lembaga Perkreditan Desa (LPD) merupakan salah satu wadah yang dapat memberikan pinjaman dan menampung segala keperluan masyarakat dalam bidang keuangan guna menunjang dan memperlancar pembangunan perekonomian di daerah pedesaan khususnya di desa adat (Darmawangsa et al., 2017). Daerah pedesaan, terutama bagi petani dan pengusaha kecil dipandang perlu mendapatkan bantuan permodalan yang bersifat lembaga dan berkesinambungan melalui pendirian Lembaga Perkreditan Desa (Wulandari, 2009).

Menurut Philip Kotler (2002) dalam (Bash, 2015) suatu lembaga keuangan harus memiliki sistem pemasaran yang baik untuk diterapkan oleh lembaganya. Salah satu strategi pemasaran yang dilakukan untuk memberikan kepuasan dan meningkatkan minat nasabah adalah melalui sistem door to door atau strategi pemasaran secara langsung. Menurut Latifah \& Putri (2020), sistematika sistem layanan door to door adalah mendatangi nasabah kerumahnya masing-masing. Salah satu lembaga keuangan yang menggunakan pendekatan pemasaran dengan sistem layanan door to door kepada nasabah yaitu LPD Desa Pakraman Ubud

Penghimpunan dana tabungan dengan sistem layanan door to door pada LPD Desa Pakraman Ubud telah dilakukan sejak LPD Desa Pakraman Ubud diaktifkan yaitu pada tahun 1999. Sejalan dengan penelitian yang dilakukan oleh Aziz (2018), sistem layanan door to door ini dilaksanakan oleh LPD Desa Pakraman Ubud untuk meningkatkan minat nasabah untuk menabung pada LPD. Pada tahun 2017 LPD Desa Pakraman Ubud menggunakan sistem dengan aplikasi mobile LPD untuk memudahkan dalam melakukan transaksi dan mengimput data ke sistem komputer.

LPD Desa Pakraman Ubud merupakan LPD yang berada di daerah pariwisata dimana kebanyakan nasabahnya berpenghasilan dari bidang pariwisata. Semenjak meluasnya penyebaran Covid-19, banyak tempat pariwisata ditutup dan kunjungan wisatawan berkurang pesat di daerah Ubud. Menurut Supriatna (2020) Virus Corona atau Covid-19 pertama kali terdeteksi muncul di Cina tepatnya di Kota Wuhan Tiongkok pada akhir tahun 2019. Dampak Covid-19 pada sektor pariwisata juga tidak luput dari ancaman. Sektor-sektor pendukung pariwisata yaitu restoran, hotel hingga pengusaha retail juga terdampak akibat pandemi Covid-19 (Block, 2017 dalam (Nasution et al., 2020)).

Berdasarkan penelitian Nasution (2020), dampak yang dialami sektor ekonomi saat pandemi Covid-19 untuk pekerja yang dirumahkan dan kena PHK, lebih dari 1,5 juta orang. Dari jumlah ini, 90 persen dirumahkan dan 10 persen terkena PHK dimana sebanyak 1,24 juta orang adalah pekerja formal dan 265 ribu pekerja informal.

Hal ini menyebabkan berkurangnya penghasilan masyarakat Desa Ubud yang merupakan sebagian besar nasabah di LPD Desa Pakraman Ubud. Sehingga menyebabkan beberapa perubahan pada sistem layanan jeput bola pada LPD Desa Pekraman Ubud seperti jumlah penerimaan setoran tabungan yang semakin berkurang pada LPD, kemudian jumlah nasabah tetap namun yang aktif menabung berkurang, dan jam operasional LPD Desa Pakraman Ubud juga berkurang. Perubahan jumlah tabungan 


\section{SULTANIST: Jurnal Manajemen dan Keuangan, Vol 9 (1), Juni 2021}

seluruh nasabah sistem layanan door to door pada LPD Desa Pakraman Ubud saat pandemi Covid-19 pada tahun 2020 dapat dilihat pada tabel dibawah ini.

Tabel 1. Jumlah Tabungan Sistem Layanan Door to Door Pada Tahun 2020

\begin{tabular}{ccc}
\hline No & Bulan & $\begin{array}{c}\text { Jumlah } \\
\text { Tabungan }\end{array}$ \\
\hline 1 & Januari & $17,085,069,987.00$ \\
2 & Februari & $17,751,596,387.00$ \\
3 & Maret & $17,408,502,687.00$ \\
4 & April & $16,762,097,187.00$ \\
5 & Mei & $16,112,439,087.00$ \\
6 & Juni & $15,645,101,187.00$ \\
7 & Juli & $15,290,538,987.00$ \\
8 & Agustus & $14,331,193,087.00$ \\
9 & September & $13,394,824,961.00$ \\
10 & Oktober & $12,768,285,694.00$ \\
11 & November & $12,350,480,887.00$ \\
12 & Desember & $11,931,590,387.00$ \\
\hline
\end{tabular}

Sumber: Data sekunder (diolah), 2021

Berdasarkan tabel diatas dapat dilihat bahwa pada tahun 2020 terjadinya peningkatan jumlah tabungan pada bulan Januari ke bulan Februari, sedangkan pada bulan Maret hingga bulan Desember terjadi tren penurunan jumlah tabungan nasabah dengan sistem layanan door to door pada LPD Desa Pakraman Ubud. Hal ini disebabkan pada bulan Januari dan bulan Februari 2020 dampak dari penyebaran Virus Corona belum begitu besar terhadap perekonomian di Bali. Hal ini sejalan dengan yang dijelaskan oleh Hadiwardoyo (2020) bahwa dimulai sejak awal Maret 2020 untuk merespon pandemi Virus Corona 2019 (Covid-19), pemerintah Indonesia mulai menerapkan pembatasan dengan kebijakan social distancing dan physical distancing. Kebijakan tersebut telah menurunkan secara drastis aktivitas dan pergerakan orang yang menyebabkan kunjungan turis yang datang ke Bali menurun begitu pesat, banyak pekerja yang dirumahkan dan terkena PHK. Hal ini tentunya berpengaruh terhadap pendapatan masyarakat Ubud yang sebagian besar berpenghasilan dari bidang pariwisata. Sehingga setoran tabungan nasabah door to door mengalami penurunan semenjak adanya pandemi Covid-19.

Dalam pelaksanaan sistem layanan door to door pada LPD Desa Pakraman Ubud tentu juga terdapat kelebihan dan kekurangan. Berdasarkan pemikiran tersebut maka peneliti ingin mengetahui karakteristik nasabah sistem layanan door to door produk tabungan, proses pencarian tabungan dengan sistem layanan door to door saat pandemi Covid-19 pada LPD Desa Pakraman Ubud, serta kelebihan dan kekurangan sistem layanan door to door produk tabungan pada LPD Desa Pakraman Ubud.

\section{LANDASAN TEORI}

Tabungan dengan Sistem Layanan Door to Door

Tabungan adalah simpanan yang penarikannya hanya dapat dilakukan menurut syarat tertentu yang disepakati, tetapi tidak dapat ditarik dengan cek atau alat yang dapat dipersamakan dengan itu (Undang-Undang No. 7 Tahun 1992 tentang perbankan sebagaimana telah diubah dengan Undang-Undang Nomor 10 tahun 1998 dalam (Rejeki, 2010)).

Menurut Aziz (2018), Sistem layanan door to door merupakan strategi pemasaran yang saat ini adalah ketika para pebisnis baik yang menjual produk atau pun jasa tidak lagi menjual produk jasanya tersebut hanya dengan menunggu kedatangan pelanggan tanpa melakukan apapun, 


\section{SULTANIST: Jurnal Manajemen dan Keuangan, Vol 9 (1), Juni 2021}

melainkan mereka akan menghubungi pelanggannya satu per satu dan secara langsung menanyakan kebutuhan akan produk atau jasa. Menghubungi di sini bisa dengan cara melakukan hubungan melalui telepon atau langsung mendatangi pelanggan ke rumahnya atau ke tempat usahanya.

Tabungan dengan sistem layanan door to door adalah sesuatu yang disimpan atau dititipkan berupa uang didalam lembaga keuangan yang dilakukan dengan mendatangi atau mencari nasabah melalui cara door to door atau dengan karyawan menjemput langsung dana atau uang yang akan disimpan oleh nasabah (Aziz, 2018).

\section{Dampak Covid-19 Terhadap Manajemen Industri Perbankan}

Regulator mengeluarkan kebijakan untuk meminimalkan dampak Covid-19, termasuk di sektor industri perbankan. Kebijakan tentang industri perbankan dikeluarkan oleh otoritas selama PSBB (SP 26/ DHMS/ OJK/ IV/ 2020). Menurut Siaran Pers dalam Operasi Industri Jasa Keuangan Selama Periode Implementasi PSBB di Berbagai Daerah. Isinya bahwa OJK meminta lembaga jasa keuangan untuk bekerja dengan jumlah minimum karyawan sesuai dengan protokol kesehatan di tempat kerja. Lembaga layanan keuangan harus mematuhi prosedur PSBB untuk diimplementasikan, seperti physical distancing, mengurangi layanan dengan tatap muka dan sebagai gantinya perbankan dapat memaksimalkan penggunaan teknologi dan selalu menjaga kesehatan (Ningsih \& Mahfudz, 2020).

\section{Penelitian Terdahulu}

Beberapa penelitian terdahulu tentang sistem layanan door to door pada lembaga keuangan yaitu pertama penelitian yang dilakukan oleh Abdul Aziz (2018) mengenai pelaksanan produk tabungan dengan sistem jemput bola pada BMT Al Fataya Cabang Guguak Lima Puluh Kota. Kemudian yang kedua yaitu penelitian yang dilakukan oleh Pareng Rejeki (2010) mengenai evaluasi sistem pelayanan tabungan jemput bola pada Kantor Kas PT. BPR Cita Dewi. Ketiga yaitu penelitian yang dilakukan oleh Nurul Azizah (2019) mengenai strategi layanan sistem jemput bola dalam meningkatkan motivasi menabung anggota pada KSU BMT Dana Mentari Muhammadiyah KC Karanglewas Purwokerto.

\section{METODE}

Penelitian ini dilaksanakan di LPD Desa Pakraman Ubud pada bulan Desember 2020 hingga bulan Januari 2021. Jenis data yang digunakan yaitu data kuantitatif dan data kualitatif dengan sumber data yaitu data primer dan data sekunder. Metode pengumpulan data yang penulis gunakan dalam penelitian ini yaitu dokumentasi dan wawancara yang dipandu dengan daftar pertanyaan. Populasi dalam penelitian ini adalah Pegawai LPd Desa Pakraman Ubud yang berjumlah 18 orang dan nasabah sistem layanan door to door produk tabungan yang berjumlah 1.690 orang. Penarikan sampel untuk pegawai LPD dalam penelitian ini menggunakan purposive sampling (secara sengaja) dimana pengambilan anggota sampel terdapat 7 orang dengan cara mengambil subjek yang memiliki tugas berkaitan dengan pelaksanaan sistem layanan door to door produk tabungan. Pengambilan sampel 
untuk nasabah menggunakan accidental sampling dan menghitung ukuran sampel yang dilakukan dengan menggunakan teknik Slovin dengan margin error sebesar $15 \%$ dan diperoleh sampel nasabah yang menjadi responden sebanyak 43 orang.

Analisis tujuan satu yaitu karakteristik nasabah dianalisis dengan penelitian deskriptif dengan pendekatan kuantitatif yang bertujuan mengungkapkan suatu apa adanya dengan menggunakan analisis tabulasi sederhana. Menurut Arikunto (2006:81) dalam (Yuriawati, 2014) persentase diperoleh dengan membandingkan jumlah frekuensi jawaban dari banyaknya sampel yang dikalikan $100 \%$. Analisis tujuan dua dan tiga yaitu proses pelaksanaan sistem layanan door to door dan kelebihan dan kekurangan sistem layanan door to door dianalisis secara deskriptif kualitatif. Teknik analisis deskriptif kualitatif yaitu menganalisis, menggambarkan dan meringkas berbagai kondisi situasi dari berbagai data yang dikumpulkan berupa hasil wawancara atau pengamatan mengenai masalah yang diteliti yang terjadi dilapangan (Rijali, 2019).

\section{HASIL DAN PEMBAHASAN}

Karakteristik Nasabah Sistem Layanan Door to Door Produk Tabunga

Tujuan dari identifikasi karakter nasabah yaitu untuk mengenali profil nasabah, sehingga dapat mengidentifikasi kemungkinan terjadinya transaksi yang tidak diinginkan (Latifah, 2019).

Karakteristik nasabah berdasarkan umur dapat dilihat pada tabel 1.

Tabel 1. Umur Responden

\begin{tabular}{cccc}
\hline No & $\begin{array}{c}\text { Umur } \\
\text { (Tahun) }\end{array}$ & $\begin{array}{c}\text { Jumlah } \\
\text { (orang) }\end{array}$ & $\begin{array}{c}\text { Persentase } \\
(\boldsymbol{\%})\end{array}$ \\
\hline 1 & $<15$ & 0 & 0
\end{tabular}

\begin{tabular}{cccc}
2 & $15-64$ & 35 & 81,4 \\
3 & $>64$ & 8 & 18,6 \\
\hline & JUMLAH & 43 & 100 \\
\hline
\end{tabular}

Sumber: Data primer (diolah), 2021

Berdasarkan tabel diatas, diketahui sebagian besar responden berumur 15-64 tahun. Sejalan dengan penelitian Fadhilla (2018) juga mengemukakan bahwa pada usia 35-44 tahun dominan dalam menentukan perilaku menabung dengan jumlah 47 orang atau 47,0\%. Berdasarkan peryataan Tjiptoherijanto (2001) kelompok umur produktif adalah usia 15 - 64 tahun. Hal ini menunjukan responden dengan umur usia kerja dimana nasabah masih menghasilkan uang untuk ditabung pada lembaga keuangan.

Status pernikahan dapat membentuk perilaku seseorang dalam mengambil sebuah keputusan dan memikirkan masa depan. Untuk itu status responden dapat dilihat pada tabel 2 .

Tabel 2. Status Resonden

\begin{tabular}{|c|c|c|c|}
\hline No & Status & $\begin{array}{l}\text { Jumlah } \\
\text { (orang) }\end{array}$ & $\begin{array}{l}\text { Persentase } \\
(\%)\end{array}$ \\
\hline 1 & Menikah & 37 & 8605 \\
\hline 2 & $\begin{array}{l}\text { Belum } \\
\text { Menikah }\end{array}$ & 6 & 13,95 \\
\hline & JUMLAH & 43 & 100 \\
\hline
\end{tabular}

Sumber: Data primer (diolah), 2021

Berdasarkan tabel di atas diketahui bahwa sebagian besar responden telah berstatus menikah. Hal ini dikarenakan sebagian besar responden pada penelitian ini merupakan responden yang telah berusia produktif yang biasanya telah menikah.

Pekerjaan berpengaruh terhadap pendapatan responden karena biasanya semakin banyak jumlah pendapatan seseorang maka semakin tinggi juga jumlah tabungan seseorang yang dimilikinya. 


\section{SULTANIST: Jurnal Manajemen dan Keuangan, Vol 9 (1), Juni 2021}

Pekerjaan responden ditunjukkan pada tabel berikut.

Tabel 3. Pekerjaan Responden

\begin{tabular}{clcc}
\hline No & Pekerjaan & $\begin{array}{c}\text { Jumlah } \\
\text { (orang) }\end{array}$ & $\begin{array}{c}\text { Persentase } \\
(\%)\end{array}$ \\
\hline \multirow{2}{*}{1} & Pegawai & & \\
2 & Swasta & 2 & 4,65 \\
3 & Pedagang & 26 & 60,46 \\
& Wiraswasta & 10 & 23,26 \\
4 & Tbu Rumah & 4 & 9,3 \\
5 & Mahasiswa & 1 & 2,33 \\
\hline & JUMLAH & 43 & 100 \\
\hline
\end{tabular}

Sumber: Data primer (diolah), 2021

Berdasarkan tabel diatas, diketahui sebagian besar responden bekerja sebagai pedagang yaitu dengan persentase $60,46 \%$. Hal ini dikarenakan saat pencarian responden penelitian sebagian besar responden ditemukan di daerah Pasar Ubud, maka dari itu sebagian besar responden bekerja sebagai pedagang.

Perbedaan jenis menyebabkan munculnya perlakuan yang berbeda terhadap laki-laki dan perempuan dalam menentukan keputusan baik untuk masa depan, dengan demikian dalam karakteristik nasabah dilihat berdasarkan jenis kelamin ditunjukkan seperti pada tabel berikut.

Tabel 4. Jenis Kelamin Responden

\begin{tabular}{ccrc}
\hline No & $\begin{array}{c}\text { Jenis } \\
\text { Kelamin }\end{array}$ & $\begin{array}{c}\text { Jumlah } \\
\text { (orang) }\end{array}$ & $\begin{array}{c}\text { Persentase } \\
(\boldsymbol{\%})\end{array}$ \\
\hline 1 & Perempuan & 35 & 81,4 \\
2 & Laki-laki & 8 & 18,6 \\
\hline & JUMLAH & 43 & 100 \\
\hline
\end{tabular}

Sumber: Data primer (diolah), 2021

Bedasarkan tabel diatas sebagian besar nasabah merupakan perempuan yaitu dengan persentase $81 \%$. Hal ini dikarenakan sebagian besar responden ditemukan di
Pasar Ubud yang bekerja sebagai pedagang yang dominan berjenis kelamin perempuan.

Daerah pemasaran tabungan dalam pelayanan jasa akan digunakan untuk melihat respon nasabah dalam menabung. Respon responden berdasarkan bagian wilayah dapat dilihat pada tabel 5 .

Tabel 5. Bagian Wilayah Responden

\begin{tabular}{clcc}
\hline No & Wilayah & $\begin{array}{c}\text { Jumlah } \\
\text { (orang) }\end{array}$ & $\begin{array}{c}\text { Persentase } \\
(\%)\end{array}$ \\
\hline \multirow{2}{*}{1} & Ubud Kelod & & \\
& Bagian Barat & 6 & 13,95 \\
& Ubud Kelod & & \\
2 & Bagian Timur & 5 & 11,63 \\
3 & Pasar & 29 & 67,44 \\
4 & Jalan Kajeng & 2 & 4,65 \\
5 & Ubud Kaja & 1 & 2,33 \\
\hline & JUMLAH & 43 & 100
\end{tabular}

Sumber: Data primer (diolah), 2021

Berdasarkan tabel diatas, bagian wilayah responden menabung sebagian besar berada di pasar yaitu sebanyak 29 orang dengan persentase $67,44 \%$. Hal ini dikarenakan sebagian besar responden ditemui di pasar.

Jumlah tabungan responden digunakan untuk melihat respon nasabah dalam menabung. Biasanya semakin makmur hidup seseorang maka semakin tinggi pula jumlah tabungannya. Pada jumlah tabungan nasabah, peneliti menggunakan skala interval dengan Rumus Sturges sehingga diperoleh rentang jumlah tabungan responden seperti pada tabel berikut.

Tabel 6. Jumlah Tabungan Responden

\begin{tabular}{cccc}
\hline No & $\begin{array}{c}\text { Jumlah } \\
\text { Tabungan }\end{array}$ & $\begin{array}{c}\text { Jumlah } \\
\text { (orang) }\end{array}$ & $\begin{array}{c}\text { Persentase } \\
(\%)\end{array}$ \\
\hline \multirow{2}{*}{1} & 64.500 & & \\
& -32.746 .105 & 40 & 93,01 \\
\hline 2 & 33.746 .106 & 1 & 2,33 \\
\hline
\end{tabular}




\begin{tabular}{|c|c|c|c|}
\hline & -65.427 .711 & & \\
\hline \multirow{2}{*}{3} & 65.427 .712 & & \\
\hline & -98.109 .317 & 1 & 2,33 \\
\hline \multirow{2}{*}{4} & 98.109 .318 & & \\
\hline & -130.790 .923 & 0 & 0 \\
\hline \multirow{2}{*}{5} & 130.790 .924 & & \\
\hline & -163.427 .530 & 1 & 2,33 \\
\hline & JUMLAH & 43 & 100 \\
\hline
\end{tabular}

Sumber: Data sekunder (diolah), 2021

Berdasarkan tabel diatas, dapat ditafsirkan hampir seluruh responden jumlah tabungannya yaitu sebesar Rp 64.500 hingga Rp 32.746.105 dengan persentase 93,01\%.

\section{Proses Pelaksanaaan Sistem Layanan Door to Door Produk Tabungan}

Proses pelaksanaan sistem layanan door to door pada LPD Desa Pakraman Ubud dilakukan oleh staf kolektor dengan mendatangi nasabah yang ingin menabung sesuai dengan pembagian wilayah yang telah diatur oleh Lembaga Perkreditan Desa (LPD). Proses pelaksanaan sistem layanan door to door pada LPD Desa Pakraman Ubud yaitu pembagian wilayah sistem layanan door to door untuk staf kolektor dibagi menjadi delapan wilayah dengan kode masing-masing yaitu Ubud Tengah dengan kode (02), Jalan Kajeng dengan kode (06), Ubud Kelod Bagian Timur dengan kode (04), Ubud Kelod Bagian Barat dengan kode (05), Sambahan dengan kode (07), Ubud Kaja dengan kode (01), Pasar dengan kode (03), Bentuyung dan Monkey Forest dengan kode (10). Kode-kode tersebut digunakan untuk pembagian staf kolektor dan mempermudah dalam melakukan transaksi. Proses pelaksaanaan sistem layanan door to door pada LPD disajikan seperti pada gambar berikut.

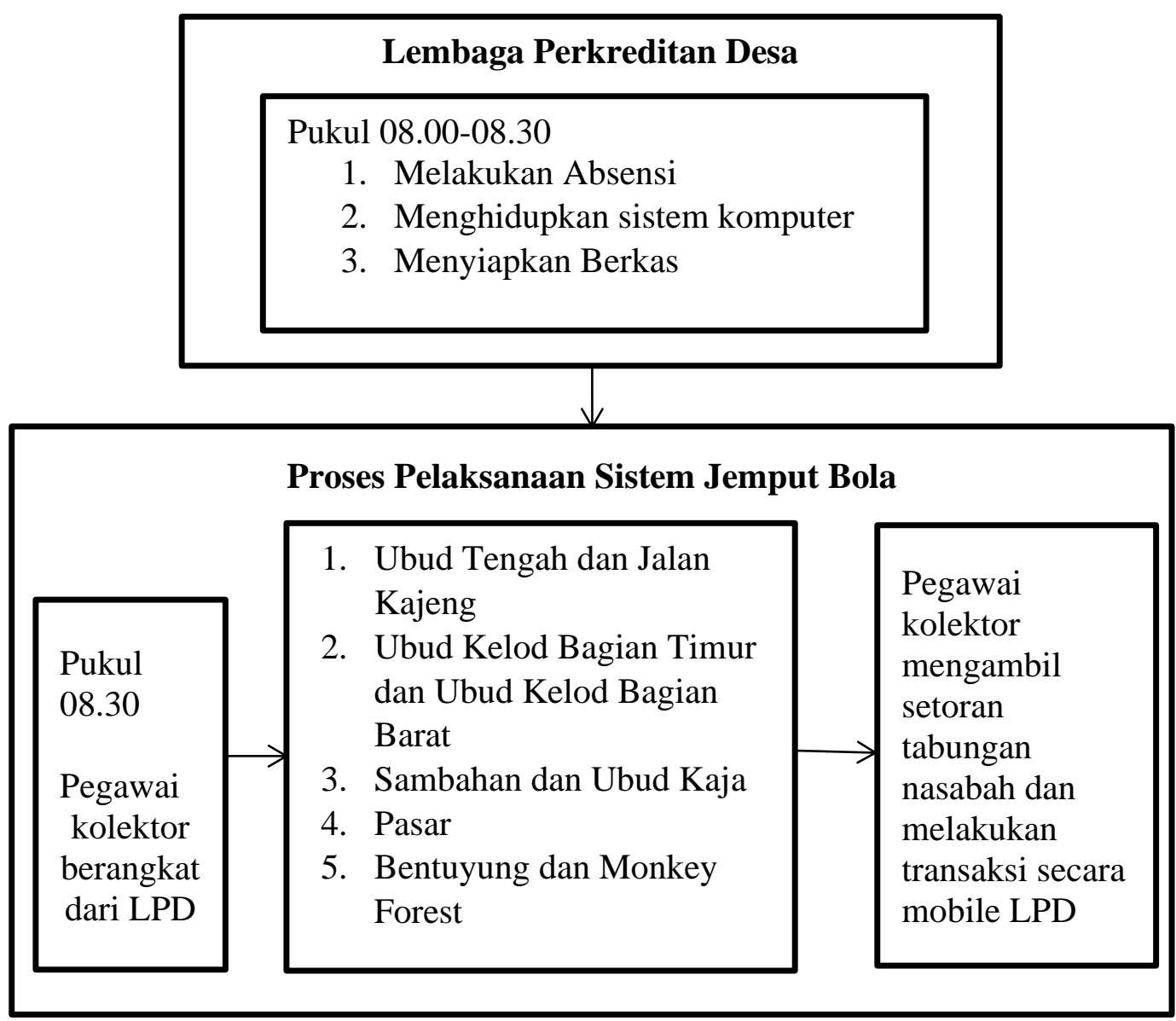

Copyright (C) 2021, SULTANIST: Jurnal Manajemen dan Keuangan

Sekolah Tinggi Ilmu Ekonomi Sultan Agung 


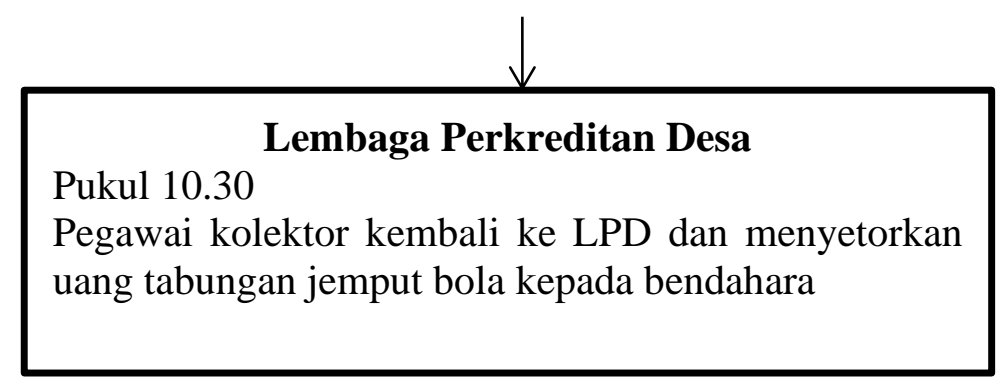

Gambar 1. Proses Pelaksanaan Sistem Layanan Jemput Bola

Proses pelaksanaan sistem layanan door to door pada LPD diawali dengan staf kolektor datang ke LPD terlebih dahulu pukul 08.00 wita untuk melakukan absensi dan menyiapkan segala keperluan untuk melaksanakan sistem layanan door to door kepada nasabah. Semenjak adanya pendemi Covid-19, staf kolektor menggunakan protokol kesehatan seperti masker dan membawa handsanitizer saat bertugas. Sebelum adanya pandemi Covid-19, staf kolektor mulai berangkat dari LPD ke nasabah-nasabah pukul 08.30-12.00 WITA. Namun semenjak adanya pandemi Covid19, staf kolektor mulai berangkat dari LPD ke nasabah-nasabah pukul 08.30 sampai 10.30 WITA. Hal ini dikarenakan sebelum adanya pandemi Covid-19, LPD Desa Pakraman Ubud beroperasi dari pukul 08.00 - 14.30 WITA, namun setelah adanya pendemi Covid-19 LPD Desa Pakraman Ubud beroperasi dari pukul 08.00-01.00 WITA saja. Sejalan dengan hasil penelitian Ningsih \& Mahfudz (2020) yaitu semenjak adanya panyebaran Virus Corona dilakukannya pembatasan layanan operasional. Batasan kegiatan layanan ini dilakukan untuk mencegah penyebaran Virus Corona. Nasabah door to door bebas menyetor tabungan berapa saja karena tidak ada minimal dan maksimal tabungan yang harus disetorkan. Nasabah door to door juga tidak diharuskan menabung setiap setiap hari. Proses transaksi menabung pada sistem layanan door to door dilakukan dengan nasabah memberikan buku tabungan dan uang yang akan disetorkan kepada staf kolektor untuk dicatat pada buku tabungan jumlah nominal tabungan yang disetorkan, kemudian diberikan cap pada buku tabungan tersebut. Selanjutnya staf kolektor akan menginput jumlah setoran yang diberikan oleh nasabah sesuai dengan kode nasabah pada aplikasi mobile LPD dan data tersebut akan langsung masuk ke program komputer pada LPD. Begitu juga dengan penarikan tabungan, namun pada penarikan tabungan juga menggunakan slip penarikan tabungan yang diisi berdasarkan jumlah nominal yang diminta oleh nasabah dan dibuat rangkap dua. Staf kolektor selalu menyetorkan uang setoran tabungan nasabah jembut bola kepada bendahara setiap hari setelah mengambil setoran tabungan dari nasabahnasabah. Pelaksanaan sistem layanan door to door dilakukan dilakukan lima kali dalam seminggu yaitu dari hari senin hingga hari jumat.

Semenjak adanya pandemi Covid-19, terjadinya penurunan jumlah nasabah yang 
aktif menabung pada LPD Desa Pakraman Ubud. Sebelum adanya pandemi Covid-19 biasanya dalam sehari untuk bagian wilayah Ubud Tengah dan Jalan Kajeng jumlah nasabah yang dikunjungi yaitu sekitar 15-25 orang, untuk wilayah Ubud Kelod Bagian Barat dan Timut yaitu sekitar 30-40 orang, untuk wilayah Sambahan dan Ubud Kaja yaitu sekitar 30-35 orang, untuk wilayah pasar yaitu sekitar lebih dari 50 orang, untuk wilayah Bentuyung dan Monkey Forest yaitu sekitar 40-50 orang. Sedangkan setelah adanya pandemi Covid-19 terjadinya penurunan jumlah nasabah yang aktif menabung, untuk bagian wilayah Ubud Tengah dan Jalan Kajeng jumlah nasabah yang dikunjungi menjadi sekitar 5-10 orang, untuk wilayah Ubud Kelod Bagian Barat dan Timur yaitu sekitar 5-10 orang, untuk wilayah Sambahan dan Ubud Kaja yaitu sekitar 15 orang, untuk wilayah pasar yaitu sekitar lebih dari 16 orang, untuk wilayah Bentuyung dan Monkey Forest yaitu sekitar 13 orang. Pandemi Covid-19 ini tentunya juga mempengaruhi jumlah setoran nasabah dimana pada saat sebelum adanya pandemi Covid-19 jumlah setoran tabungan staf kolektor kepada bendahara mencapai Rp 137.884.500,00 per 2 Januari 2020 dan setelah adanya pandemi Covid-19, jumlah setoran tabungan staf koletor kepada bendahara hanya mencapai $\mathrm{Rp}$ 41.789.800,00 per 18 Januari 2021. Hal ini menunjukkan semenjak adanya pandemi Covid-19 menyebabkan terjadinya penurunan jumlah setoran tabungan kurang kebih sekitar $70 \%$ dimana hal ini memberikan dampak yang cukup besar terhadap LPD.

Kelebihan dan Kekurangan Sistem Layanan Door to door
Menurut Aziz (2018) dijelaskan bahwa dalam menerapkan strategi pemasaran dengan sistem door to door terdapat banyak sekali manfaat yang bisa diperoleh. Kelebihan sistem layanan door to door pada LPD Desa Pakraman Ubud yaitu waktu yang digunakan menjadi lebih efisien, syarat pembukaan tabungan sangat mudah dan sudah memenuhi standar operasional yang ditetapkan. memudahkan mendapatkan informasi mengenai LPD atau nasabah, telah adanya kerjasama yang baik antar fungsi yang terkait, sehingga dapat memperkecil kecurangan yang mungkin terjadi, syarat pembukaan tabungan sangat mudah dan sudah memenuhi standar operasional yang ditetapkan, terdapat register nasabah dan register mutasi tabungan, dokumen yang dipergunakan sudah dibuat rangkap dan divalidasi oleh bagian yang berwenang, proses transaksi menggunakan aplikasi mobile LPD sehingga memudahkan dalam pencatatan transaksi, catatan akuntansi yang digunakan telah menggunakan sistem komputerisasi sehingga data yang diperoleh lebih akurat. Sedangkan untuk kelemahannya sulit untuk memberikan pemahaman kepada petugas atau staf kolektor atau SDM dari LPD agar mereka paham dengan sistem layanan door to door serta mereka mau dan mampu untuk mengabdi kepada LPD, selain itu kelemahan sistem door to door pada LPD Desa Pakraman Ubud yaitu ketika tidak ada sinyal dalam handphone staf kolektor saat menjalankan tugas karena menggunakan aplikasi mobile LPD dimana hal ini dapat menyulitkan dalam melakukan transasksi.

\section{SIMPULAN DAN SARAN}

Simpulan 


\section{SULTANIST: Jurnal Manajemen dan Keuangan, Vol 9 (1), Juni 2021}

Berdasarkan penelitian yang telah dilakukan dapat disimpulkan terdapat perubahan proses pelaksanaan sistem layanan door to door pada LPD Desa Pakraman Ubud pada saat pandemi Covid19 dari sebelumnya dimana ada beberapa hal yang harus disesuaikan dengan kondisi saat pandemi Covid-19 seperti pada saat ini.

\section{Saran}

Keterbatasan dalam penelitian ini adalah masih kurang luas cakupan wilayah dalam pengambilan sampel nasabah dikarenakan adanya pandemic Covid-19. Agar mendapatkan hasil yang lebik baik lagi, maka saran dalam penelitian ini peneliti selanjutnya diharapkan untuk memperluas ruang lingkup wilayah penelitian dan lokasi penelitian sehingga hasil penelitian dapat diimplementasikan secara umum.

\section{DAFTAR PUSTAKA}

Aziz, A. (2018). Pelaksanaan Produk Tabungan Dengan Sistem Jemput Bola Pada Bmt Al Fataya Cabang Guguak Lima Puluh Kota. SKRIPSI.

Bash, E. (2015). The State Of The Art Marketing. PhD Proposal, 1(October), 2016. https://doi.org/10.1017/CBO97811074 15324.004

Darmawangsa, I. G. N. R., Mertha, I. K., \& Sarjana, I. M. (2017). Tanggungjawab Pengurus Lpd Dalam Pengelolaan Keuangan Desa Pakraman. Acta Comitas, 2(2), 183-188. https://media.neliti.com/media/publicat ions/241406-tanggungjawab-penguruslpd-dalam-pengelo-6f50d685.pdf

Fadhilla, M. A. (2018). Faktor-Faktor Yang Mempengaruhi Perilaku Nasabah Menabung Di Bank Syariah Kota Makassar. 136.
Hadiwardoyo, W. (2020). Kerugian Ekonomi Nasional Akibat Pandemi Covid-19 [National Economic Losses Due to the Covid-19 Pandemic]. Baskara Journal of Business and Enterpreneurship, 2(2), 83-92. https://doi.org/10.24853/baskara.2.2.83 $-92$

Latifah, E., \& Putri, D. A. (2020). Strategi Sharia' Marketing Pick Up Service Koperasi Syariah TKI Artha Mulya Lamongan. Pamator Journal, 13(1), 154-158.

https://doi.org/10.21107/pamator.v13i1 .7161

Latifah, L. (2019). Analisis faktor-faktor yang memengaruhi minat nasabah pada produk tabungan berjangka di BMT usaha gabungan terpadu (UGT) Sidogiri Capem Galis Bangkalan. 116. http://digilib.uinsby.ac.id/31055/

Nasution, D. A. D., Erlina, E., \& Muda, I. (2020). Dampak Pandemi COVID-19 terhadap Perekonomian Indonesia. Jurnal Benefita, 5(2), 212. https://doi.org/10.22216/jbe.v5i2.5313

Ningsih, M. R., \& Mahfudz, M. S. (2020). Dampak Pandemi Covid-19 Terhadap Manajemen Industri Perbankan Syariah: Analisis Komparatif. Point, 2(1), 1-10. https://doi.org/10.46918/point.v2i1.576

Rejeki, P. (2010). Evaluasi Sistem Pelayanan Tabungan Jemput Bola Pada Kantor Kas Pt . Bpr Cita Dewi. 53.

Rijali, A. (2019). Analisis Data Kualitatif. Alhadharah: Jurnal Ilmu Dakwah, 17(33), 81. https://doi.org/10.18592/alhadharah.v1 $7 \mathrm{i} 33.2374$

Supriatna, E. (2020). Wabah Corona Virus Disease (Covid 19) Dalam Pandangan Islam. SALAM: Jurnal Sosial Dan $\begin{array}{lll}\text { Budaya } & \text { Syar-I, }\end{array}$ 


\section{SULTANIST: Jurnal Manajemen dan Keuangan, Vol 9 (1), Juni 2021}

https://doi.org/10.15408/sjsbs.v7i6.152 47

Tjiptoherijanto, P. (2001). Proyeksi Penduduk, Angkatan Kerja, Tenaga Kerja, dan Peran Serikat Pekerja dalam Peningkatan Kesejahteraan Prijono. Majalah Perencanaan Pembangunan, $23,1-10$.

Wulandari, P. P. A. (2009). PEngaruh Tabungan Dan Deposito Terhadap Posisi Kredit Pada Lpd Desa Adat Mas Kecamatan Ubud, Kabupaten Gianyar. In SKRIPSI.

Yuriawati, N. A. (2014). Ning Aneu Yuriawati , 2014 Optimalisasi Peran Strategis Pelayanan Di Wilayah
Kecamatan Dalam Mendukung Pemerintahan Yang Baik Universitas Pendidikan Indonesia repository.upi.edu. 58-83.

\section{PROFIL SINGKAT}

$\mathrm{Ni}$ Wayan Rina Yanti merupakan mahasiswa Program Studi S1 Agribisnis tahun 2017 Universitas Udayana, Bali, Indonesia. I Ketut Suamba, merupakan Dosen Fakultas Pertanian Prodi S1 Agribisnis Universitas Udayana, Bali, Indonesia. Gede Mekse Korri Arisena, merupakan Dosen Fakultas Pertanian Prodi S1 Agribisnis Universitas Udayana, Bali, Indonesia. 